WHC-EP-0895

Revision 0

\title{
B Plant Transition Project Management Plan
}

\author{
J. W. Gehrke \\ S. D. Godfrey \\ D. R. Speer
}

Date Published

April 1996

Prepared for the U.S. Department of Energy Office of Environmental Restoration and Waste Management

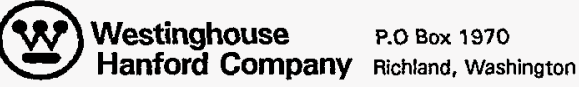

Management and Operations Contractor for the

U.S. Department of Energy under Contract DE-AC06-87RL10930

Approved for public release; distribution is unlimited 


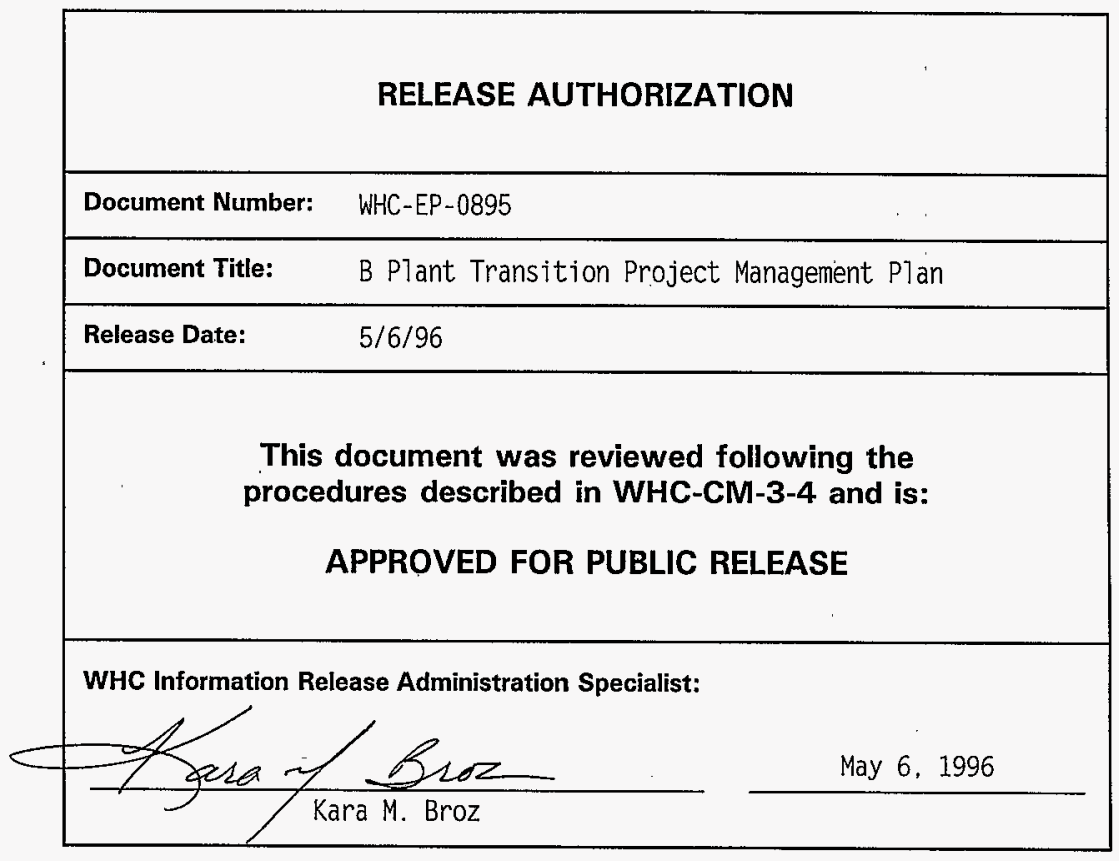


LEGAL DISCLAMMER

This report was prepared as an account of work sponsored by an agency of the United States Government. Neither the United States Government nor any agency thereof, nor any of their omployees, nor any of their contractors, subcontractors or their employees, makes any warranty, express or implied, or assumes any legal liability or responsibility for the accuracy, completeness, or any third party's use or the results of such use of any information, apparatus, product, or process disclosed, or represents that its use would not infringe privately owned rights. Reference herein to any specific commercial product, process, or service by trade name, trademark, manufactures, or otherwise, does not necessarily constitute or imply its endorsement, recommendation, or favoring by the United States Government or any agency thereof or its contractors or subcontractors. The views and opinions of authors expressed herein do not necessarily state or reflect those of the United States Government or any agency thereof.

This report has been reproduced from the best available copy. Available in paper copy and microficho.

Available to the U.S. Depertment of Energy and its contractors from

Office of Scientific and Technical Information

P.O. Box 62

Oak Ridge, TN 37831

(615) 576-8401

Avallable to the public from the U.S. Department of Commerce National Technical Information Service

5285 Port Royal Road

Springfield, VA 22161

(703) $487-4650$

Printed in the United States of Americe

DISCLM-1.CHP (1-91) 
THIS PAGE INTENTIONALLY LEFT BLANK 


\section{APPROVALS}

Document title:

Prepared by:

Approved by:

Approved by:

Approved by:
B Plant Transition Project Management Plan

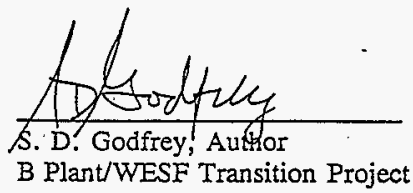

\section{$4 / 17 / 96$ \\ Date}

J. C. Midgett, Director

B Plant/WESF Transition Project

$\frac{\text { Savil } \div \text {. Earot }}{\text { D. T. Evans, RL Program Manager }} \frac{4 / 24 / 96}{\text { Date }}$ B Plant/WESF Transition Project

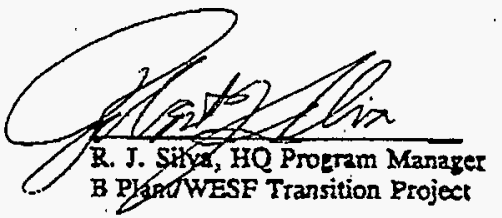

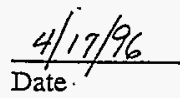

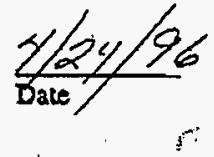


THIS PAGE INTENTIONALLY LEFT BLANK 


\section{CONTENTS}

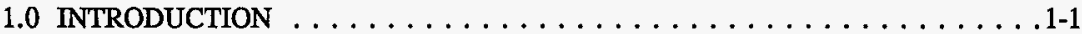

1.1 BACKGROUND . . . . . . . . . . . . . . . . .1-1

1.2 PROJECT MANAGEMENT PLAN OVERVIEW $\ldots \ldots \ldots \ldots \ldots \ldots 1-2$

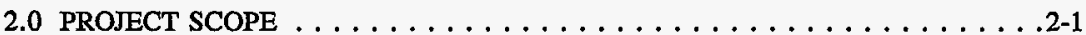

3.0 PROJECT OBJECTIVES $\ldots \ldots \ldots \ldots \ldots \ldots \ldots \ldots \ldots \ldots$. . . . . . . . .

4.0 PROJECT ORGANIZATION $\ldots \ldots \ldots \ldots \ldots \ldots \ldots \ldots \ldots \ldots$. $\ldots \ldots \ldots$

4.1 PROJECT MANAGEMENT TEAM $\ldots \ldots \ldots \ldots \ldots \ldots \ldots \ldots$. . . . . .

4.2 WHC PROJECT MANAGEMENT STRUCTURE $\ldots \ldots \ldots \ldots \ldots$. . . . . .

5.0 PROJECT MANAGEMENT AND CONTROL $\ldots \ldots \ldots \ldots \ldots \ldots$. . . . . . .

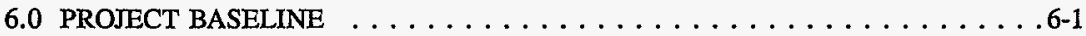

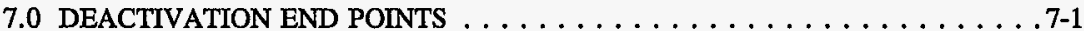

7.1 EARLY ASSUMPTIONS FOR B PLANT $\ldots \ldots \ldots \ldots \ldots \ldots \ldots$ 7-1

7.2 END POINTS METHOD $\ldots \ldots \ldots \ldots \ldots \ldots \ldots \ldots \ldots \ldots \ldots$

8.0 QUALITY ASSURANCE $\ldots \ldots \ldots \ldots \ldots \ldots \ldots \ldots \ldots$. $\ldots \ldots \ldots$

8.1 QUALITY POLICIES $\ldots \ldots \ldots \ldots \ldots \ldots \ldots \ldots \ldots . \ldots \ldots$. $\ldots \ldots \ldots$

8.2 CONFIGURATION MANAGEMENT $\ldots \ldots \ldots \ldots \ldots \ldots \ldots$. . . . . .

8.3 DOCUMENTS AND RECORDS $\ldots \ldots \ldots \ldots \ldots \ldots \ldots \ldots \ldots \ldots \ldots$

9.0 ENVIRONMENT, SAFETY AND HEALTH $\ldots \ldots \ldots \ldots \ldots$. . . . . . 9-1

9.1 ENVIRONMENTAL REGULATORY STRATEGY . . . . . . . . . . 9-1

9.2 HEALTH AND SAFETY STRATEGY $\ldots \ldots \ldots \ldots \ldots \ldots \ldots$. . . . .

9.2.1 Safety Basis Evaluation of Activities $\ldots \ldots \ldots \ldots \ldots \ldots$. . . .

9.2.2 Assessment of Hazards . . . . . . . . . . . . . . 9-5

9.2.3 Worker Safety . . . . . . . . . . . . . .6

10.0 COMMUNICATIONS AND PUBLIC INVOLVEMENT $\ldots \ldots \ldots \ldots \ldots$ 10-1

10.1 COMMUNICATION OBJECTIVES $\ldots \ldots \ldots \ldots \ldots \ldots \ldots \ldots \ldots$ 10-1

10.2 COMMUNICATION AUDIENCES . . . . . . . . . . . . . . . 10-1

10.3 STRATEGY FOR INVOLVEMENT OF INTERESTED PARTIES $\ldots . .10-2$

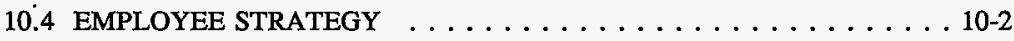

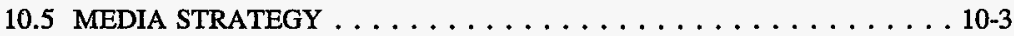

10.6 COMMUNICATIONS METHODS, CHANNELS, FORMATS, AND DISTRIBUTION $\ldots \ldots \ldots \ldots \ldots \ldots \ldots \ldots \ldots \ldots \ldots \ldots \ldots$ 10-3 


\section{CONTENTS (Continued)}

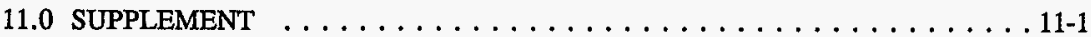

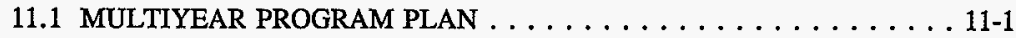

11.2 B PLANT DEACTIVATION END POINTS $\ldots \ldots \ldots \ldots \ldots \ldots \ldots$

11.3 SURVEILLANCE AND MAINTENANCE PLAN . . . . . . . . . . . $11-1$

11.4 PRECLOSURE WORK PLAN . . . . . . . . . . . . . 11-2

\section{LIST OF FIGURES}

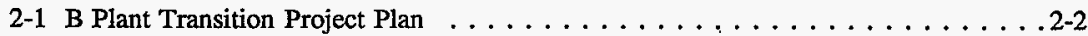

4-1 B Plant/WESF Transition Project Management Organization $\ldots \ldots \ldots \ldots$. . . .

5-1 WBS - B Plant Transition Project $\ldots \ldots \ldots \ldots \ldots \ldots \ldots \ldots \ldots . \ldots \ldots$ 5-2

6-1 B Plant Transition Project - Baseline Schedule . . . . . . . . . . . . . 6-2

\section{LIST OF TABLES}

2-1 B Plant Transition Project Buildings/Facilities $\ldots \ldots \ldots \ldots \ldots \ldots \ldots$ 2-3 


\section{DEFINITIONS}

Acceptance Criteria. A set of DOE-HQ approved criteria, as discussed in Section 8 of the Tri-Party Agreement, which ensure a facility has: 1) successfully completed the facility transition phase, 2) prepared surveillance and maintenance (S\&M) plan, and 3) maintained the S\&M plan as a current document. As a result of meeting these conditions, the DOE Office of Environmental Restoration makes a determination of whether to accept the facility into the S\&M phase (until a priority decision is made to disposition the facility).

B Plant. Old Hanford plutonium recovery and separations facility converted in 1968 for waste fractionation. Includes process buildings 221-B and 212-B, ancillary buildings and support structures, mobile offices, plant systems and utilities, underground radioactive waste lines, and underground filters and effluent lines.

Data Quality Objective (as used for a planning process). The formal decision making process between the laboratory and the client that defines necessary analytical requirements based on the end-use of the data.

Deactivation. Activities associated with removing facility systems and/or areas from operational service with the intent of being ready for facility transition to either convert the facility for another use or move to permanent shutdown. These activities could include the removal of fuel, draining and/or de-energizing of systems, removal of accessible stored radioactive and hazardous materials and other actions to place the facility systems and/or areas in a safe and stable condition so that a surveillance and maintenance program will be able to most cost effectively prevent any unacceptable risk to the public or the environment until ultimate disposition of the facility. (Note: These activities are usually conducted during the facility transition phase.)

Decontamination. The process of removing radioactive and/or hazardous contamination from facilities, equipment, or soils by physical removal, washing, heating, chemical action, mechanical cleaning, or other techniques to achieve a stated objective or end condition.

Entombment. The remedial process to encapsulate a facility in place as a method of final disposition once cleanout has been completed.

Facility (as applied to the Facility Decommissioning Process). A free-standing building, plant, laboratory, or other enclosure and associated buildings and disposal sites under its responsibility that fulfills, or fulfilled, a specific purpose, and is owned by or otherwise under the responsibility of the DOE-HQ. (Note: This usage differs substantially from that in the Comprehensive Environmental Response, Compensation, and Liability Act [CERCLA] and Resource, Conservation and Recovery Act [RCRA]). 
Facility Decommissioning Process. The sequential phases for a facility, once a shutdown decision is made by DOE-HQ, beginning with facility transition, through surveillance and maintenance (S\&M), and final facility disposition.

Facility Disposition Phase. Final period in the life of a facility. This phase occurs when no future use is identified as part of the DOE-HQ facility assessment process and priority is given to proceed with disposition. This phase primarily involves processes to achieve a final end state for the facility (e.g., entombment, and/or dismantlement and site restoration), including closure of any treatment, storage and disposal units (TSDs). Facility disposition may be integrated with cleanup of past-practice units covered under CERCLA Remedial Action or RCRA Corrective Measure Authority.

Facility End Point Criteria (as used during facility transition phase). Facility-specific criteria prepared during facility transition planning to support development of the transition planning documentation, work plans, and ultimately the Project Management Plan. Collectively these criteria provide a technical description of the acceptable state of facility components to be achieved at the end of the facility transition phase and are prepared consistent with EM acceptance criteria objectives outlined in the Office of Environmental Management Decommissioning_Resource Manual. This definition includes a status of how tanks, piping, rooms/areas and miscellaneous systems and equipment will be left at the end of the transition phase for a period of surveillance and maintenance prior to final disposition. (Note: End point criteria for regulated units and hazardous substances that will remain in the facility following transition will be approved by the regulators.)

Facility Surveillance and Maintenance (S\&M) Phase. Period in the life of a facility following completion of the transition phase until such time as the facility is dispositioned for other use, or facility disposition has commenced. The S\&M program provides direction, management, and performance assessments to be carried out in accordance with an approved S\&M Plan. The S\&M phase ensures that facilities are maintained in a safe and environmentally sound manner until a final disposition occurs. In addition, the S\&M level of effort will be established in the S\&M Plan to minimize the costs of final disposition (i.e. as low as economically achievable) whether the facility is planned by DOE-HQ to be released for alternate use or for dismantlement and site restoration, and/or entombment under the facility disposition phase.

Facility Transition Phase. A period of time during which activities necessary to place the subject facility in a safe, stable, and environmentally sound condition, suitable for an extended period of surveillance and maintenance pending final disposition are completed. Facility transition starts with termination of operations, includes the establishment of a S\&M program, and ends with the achievement of facility-specific end point criteria.

These actions could include the collective conversion of the facility for potential other uses or permanent shutdown; by the removal of fuel, draining and/or de-energizing of systems, removal of accessible stored radioactive and hazardous materials and other deactivation actions to place the facility in a safe and stable condition for the surveillance and 
maintenance program. This phase usually involves stabilization and deactivation processes and may also include some decontamination activities necessary to effectively result in reduced S\&M cost for the facility. (Note: Facility transition documentation describing end point criteria for regulated units and hazardous substances that will remain in the facility following transition will be approved by the regulators.)

Preclosure Work Plan. Document prepared in cases where completion of RCRA closure activities during the transition or S\&M phases is impracticable. The preclosure work plan details actions to be completed during the transition phase in order to facilitate full RCRA closure in the future. These efforts may include removal of dangerous wastes and hazardous substances and/or removal or decontamination of equipment or structures contaminated with dangerous wastes or hazardous substances.

S\&M Surplus Facilities. Facilities on the Hanford Site transferred from DOE Operations to the surveillance and maintenance phase under the responsibility of EM (Office of Environmental Restoration) prior to the establishment of the EM (Office of Facility Transition). The facility decommissioning process for these special case facilities will be completed entirely under the disposition phase funded on a DOE-HQ priority basis by EM (Office of Environmental Restoration).

Shutdown Decision. A formal DOE-HQ documented determination that a facility is surplus (see surplus facility).

Surplus Facility. Any facility or site (including equipment) that has no identified programmatic use by the operating phase Program Secretarial Officer.

Surveillance and Maintenance. Activities conducted to assure that a site or facility remains in a physically safe and environmentally secure condition, and includes periodic inspections and monitoring of the property, appropriate contamination control actions, and required maintenance of barriers controlling access. (Note: This process continues as a best management practice through the facility disposition phase until final disposition is achieved as defined in Section 8.0 of the Tri-Party Agreement.) 


\section{LIST OF TERMS}

$\begin{array}{ll}\text { BCE } & \text { B Plant Chemical Effluent Stream } \\ \text { CBC } & \text { B Plant Cooling Water Stream } \\ \text { DOE-HQ } & \text { U.S. Department of Energy, Headquarters } \\ \text { ER } & \text { Environmental Restoration } \\ \text { ISB } & \text { Interim Safety Basis } \\ \text { JSA } & \text { Job Safety Analysis } \\ \text { MOA } & \text { Memorandum of Agreement } \\ \text { MYPP } & \text { MultiYear Program Plan } \\ \text { NEPA } & \text { National Environmental Policy Act } \\ \text { NHPA } & \text { National Historic Preservation Act } \\ \text { PHSA } & \text { Preliminary Hazards/Screening Assessment } \\ \text { PMP } & \text { Project Management Plan } \\ \text { RCRA } & \text { Resource Conservation and Recovery Act } \\ \text { RL } & \text { U.S. Department of Energy, Richland Operations Office } \\ \text { S\&M } & \text { surveillance and maintenance } \\ \text { SEPA } & \text { State Environmental Policy Act } \\ \text { SSC } & \text { structures, systems, and components } \\ \text { TEDF } & \text { Treated Effluent Disposal Facility } \\ \text { TPA } & \text { Tri-Party Agreement } \\ \text { TSD } & \text { treatment, storage and disposal } \\ \text { USQ } & \text { Unreviewed Safety Question } \\ \text { WBS } & \text { work breakdown structure } \\ \text { WESF } & \text { Waste Encapsulation and Storage Facility }\end{array}$




\subsection{INTRODUCTION}

The mission of the B Plant Transition Project is to place B Plant and its ancillary facilities (referred to as B Plant throughout this document) in a safe and stable condition which requires minimal long term surveillance and maintenance (S\&M), thereby reducing the risks associated with the current radiological and chemical inventory and the costs for S\&M until disposition. Transition may include activities such as removal of stored radioactive and hazardous materials, safe shutdown of support systems such as electrical circuits and ventilation, and installation of new or modified systems required to support S\&M for a 10 year period. The goal of this Project is to complete B Plant transition activities by September 30, 1998. During transition, the Waste Encapsulation and Storage Facility will be isolated from B Plant for stand alone operation. Upon completion of transition, B Plant will be turned over to the Office of Environmental Restoration (EM-40) for the S\&M phase of B Plant decommissioning.

\subsection{BACKGROUND}

The B Plant Complex at the U.S. Department of Energy, Hanford Site is located in the south central region of Washington State. B Plant was constructed between 1943 and 1945 to process spent nuclear fuels in support of the Manhattan Project. After its original mission was completed, the plant was modified between 1961 and 1967 for the recovery, separation, and purification of strontium (Sr) and cesium (Cs) contained in the mixed fission product waste stream generated during prior fuel reprocessing operations. The recovered, purified, and concentrated $\mathrm{Sr}$ and $\mathrm{Cs}$ solutions were then transferred to the newly constructed (1974) Waste Encapsulation and Storage Facility (WESF) for conversion, encapsulation, and storage. These $\mathrm{Sr}$ and $\mathrm{Cs}$ separation campaigns were conducted at B Plant from 1968 to 1985 .

There is a substantial quantity of radioactive inventory remaining in B Plant in the form of stored liquid aqueous and organics, kilocurie quantities of particulate $\mathrm{Sr}$ and $\mathrm{Cs}$ solids contained in underground filters, and a highly contaminated facility structure.

In May of 1991 the U.S. Department of Energy, Richland Operations Office (RL) eliminated $B$ Plant from any future processing missions due to the difficulties of bringing a 46 year old plant up to current environmental standards. Since that time, B Plant has been maintained to ensure safe storage and management of substantial radioactive contamination and residual inventory from past operations, as well as supporting safe storage of approximately 75 megacuries of encapsulated Sr and Cs in WESF.

In September 1995, the Office of Waste Management (EM-30) and the Office of Nuclear Material and Facility Stabilization (EM-60) signed a Memorandum of Agreement (MOA) to 
place B Plant in transition. Included in the MOA is the decoupling of B Plant from WESF, which will continue its mission of providing safe storage and management of Hanford's Sr and $\mathrm{Cs}$ capsule inventory.

\subsection{PROJECT MANAGEMENT PLAN OVERVIEW}

This Project Management Plan (PMP) is prepared for the transition phase of B Plant decommissioning, in accordance with Hanford Federal Facility Agreement and Consent Order (Tri-Party Agreement), Sixth Amendment, Section 8.0, "Facility Decommissioning Process." The intent of the transition phase PMP is to describe how B Plant transition activities will be managed. It also contains scope, cost, and schedule information, and summarizes major project targets and Tri-Party Agreement (TPA) milestones. A separate PMP will be developed for the disposition phase of B Plant decommissioning.

The PMP is organized into two major sections, as described below:

Strategic Management Plan - describes the high level vision for B Plant transition, including project scope, project objectives, and key strategies for accomplishing the transition work. In addition, this section describes the project management approach that will be used throughout the transition phase of B Plant decommissioning, including management structure, roles, responsibilities, and interfaces with stakeholders.

Supplement - four major documents are contained as Supplements:

1) MultiYear Program Plan - which contains detailed costs, schedules, and deliverables associated with $\mathrm{B}$ Plant transition activities,

2) End Point Criteria Document - which contains facility specific transition end point criteria and established end points (acceptable final conditions of systems and spaces following transition),

3) Preclosure Work Plan - which contains B Plant TSD unit information and related actions that will be completed during the transition phase to facilitate full Resource, Conservation, and Recovery Act (RCRA) closure in the future, and

4) Surveillance and Maintenance Plan - which specifies actions that will be performed during the S\&M phase of B Plant decommissioning.

The Strategic Management Plan (main body) of the PMP will be issued, updated, and maintained as an "external publication," in accordance with WHC-CM-3-6, "Uniform Publications System." The Supplement to the PMP will contain the most recent revision of each of the four documents indicated above. These specific documents will be issued, updated, and maintained separately from the main body of the PMP, as specified in 
Section 11.0. This approach will allow for flexible and cost effective change control of the PMP. The main body of the PMP is written in a way that only major strategic changes will require a change to the document. The Supplements will require more frequent updates, as these documents contain much more detailed information. Persons reviewing and/or using this document should ensure they have the latest release of each separate document contained within the PMP. 
WHC-EP-0895, Rev. 0

This page intentionally left blank. 


\subsection{PROJECT SCOPE}

The B Plant Transition Project scope includes deactivation of B Plant process buildings (221-B and 212-B), ancillary support structures (271-B, 211-B, 291-B area, etc.), mobile offices, plant systems and utilities, underground filters, and waste sites associated with B Plant.

The location of each building/facility is shown graphically in Figure 2-1. A complete list of these buildings/facilities and a brief description is shown in Table 2-1. The boundary of the B Plant Transition Project scope, as shown in Figure 2-1, surrounds approximately 50 buildings. As shown, this boundary excludes 225-B (WESF), approximately 20 active WESF support facilities, and the 224-B facility. The project boundary encompasses all facilities and waste sites included in the B Plant transition work scope. Facilities and waste sites outside of this work scope are not shown in Figure 2-1, unless for reference or information purposes.

Deactivation work scope to be accomplished during B Plant transition is described in Section 7.0 and will be performed to meet specific end points established in the End Point Criteria Document (Section 11.2). 
WHC-EP-0895, Rev. 0

Figure 2-1. B Plant Transition Project Plan.

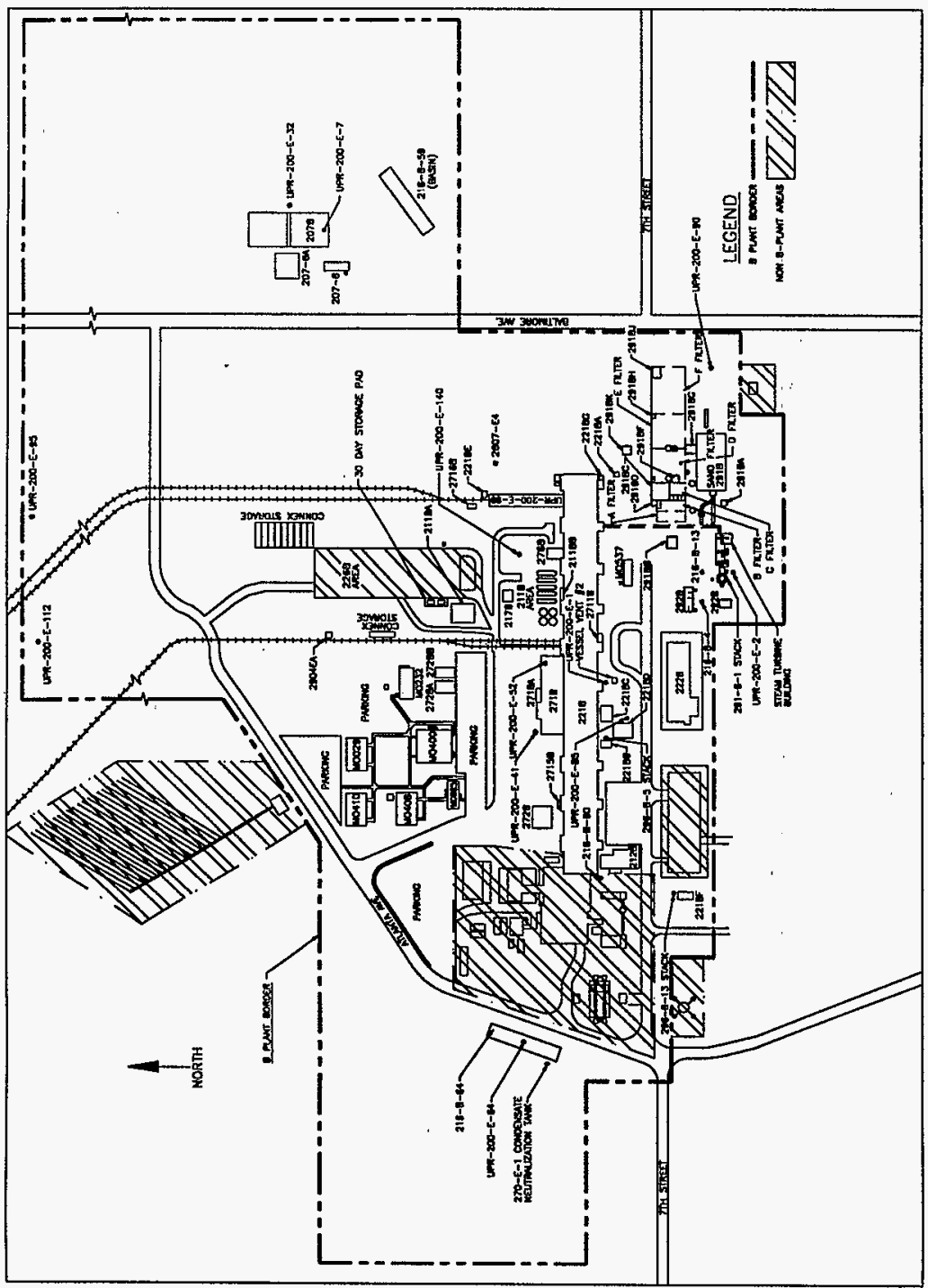


WHC-EP-0895, Rev. 0

Table 2-1. B Plant Transition Project Buildings/Facilities.

\begin{tabular}{|c|c|}
\hline 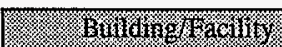 & Description \\
\hline $207 \mathrm{~B}^{*}$ & Cooling Water Retention Basin \\
\hline $207 \mathrm{~B}$ & SWP Change Trailer \\
\hline $207 \mathrm{BA}^{*}$ & CBC Sampling Bldg \\
\hline $211 \mathrm{~B}^{*}$ & Chemical Tank Farm \\
\hline $211 \mathrm{BA}^{*}$ & Chemical Sewer Neutralization Bldg \\
\hline $211 \mathrm{BB}$ & MCC Building \\
\hline $212 \mathrm{~B}^{*}$ & Cask Transfer Station \\
\hline $216-\mathrm{B}-4^{*}$ & Reverse Well for $291 \mathrm{~B}$ and $292 \mathrm{~B}$ \\
\hline $216-\mathrm{B}-13^{*}$ & French Drain for 291 B \\
\hline $216-\mathrm{B}-59^{*}$ & 15" Cooling Water Retention Basin \\
\hline $216-\mathrm{B}-60^{*}$ & Retired Crib \\
\hline $216-\mathrm{B}-64^{*}$ & Steam Condensate Retention Basin \\
\hline $217 \mathrm{~B}^{*}$ & Demineralizer Bldg \\
\hline $221 \mathrm{~B}$ & $\begin{array}{l}\text { B Plant Canyon Bldg } \\
\text { - Canyon* } \\
\text { - Electrical Gallery* } \\
\text { - Pipe Gallery* } \\
\text { - Operating Gallery* } \\
\text { - SWP Change Room } \\
\text { - Railroad Tunnel }\end{array}$ \\
\hline $221 \mathrm{BA}^{*}$ & 15" Cooling Water Monitor Bldg \\
\hline $221 \mathrm{BB}^{*}$ & Condensate Bldg for LLW Concentrator \\
\hline $221 \mathrm{BC}$ & SWP Change Bldg \\
\hline $221 \mathrm{BD}$ & Laundry Storage \\
\hline $221 \mathrm{BE}$ & Fork Lift Station \\
\hline $221 \mathrm{BF}^{*}$ & BCP Storage Pit \\
\hline $221 \mathrm{BG}^{*}$ & 24" Cooling Water Monitor Bldg \\
\hline $222 \mathrm{~B}$ & Office Bldg \\
\hline $270-\mathrm{E}-1^{*}$ & Condensate Collection Tank \\
\hline 2607-EA & Septic Tank \\
\hline
\end{tabular}


Table 2-1. B Plant Transition Project Buildings/Facilities.

\begin{tabular}{|c|c|}
\hline Ifinfung Fracility & Gescription \\
\hline $271 \mathrm{~B}$ & $\begin{array}{l}\text { B Plant Support Bldg } \\
\text { - Basement } \\
\text { - First Floor" } \\
\text { - Second Floor } \\
\text { - Third Floor" }\end{array}$ \\
\hline $271 \mathrm{BA}$ & Laundry Storage \\
\hline $2711 \mathrm{~B}$ & Breathing Air Compressor Bldg \\
\hline $2715 \mathrm{~B}^{*}$ & Paint and Oil Storage Bldg \\
\hline $2716 \mathrm{~B}$ & Laundry Storage - RR Tunnel \\
\hline $272 \mathrm{~B}$ & Electrical Shop \\
\hline $272 \mathrm{BA}$ & Maintenance and Material Storage Bldg \\
\hline $272 \mathrm{BB}$ & Insulation Shop \\
\hline $276 \mathrm{~B}^{\circ}$ & Paint Shop \\
\hline $2904 \mathrm{EA}^{*}$ & Chemical Sewer Sample Bldg \\
\hline $291 \mathrm{~B}^{*}$ & Main Stack/Sand Filter/Turbine Bldg \\
\hline $291 \mathrm{BA}^{*}$ & Exhaust Air Sample House \\
\hline $291 \mathrm{BB}^{*}$ & Instrument Bldg - A and B Filters \\
\hline $291 \mathrm{BC}^{*}$ & A and B Filters \\
\hline $291 \mathrm{BD}^{*}$ & C Filter and Instrument Bldg \\
\hline $291 \mathrm{BF}^{*}$ & D Filter \\
\hline $291 \mathrm{BG}^{*}$ & D Filter Instrument Bldg \\
\hline $291 \mathrm{BH}^{*}$ & E Filter \\
\hline $291 \mathrm{BJ}^{*}$ & F Filter \\
\hline $291 \mathrm{BK}^{*}$ & Instrument Bldg - $\mathrm{E}$ and $\mathrm{F}$ Filters \\
\hline $292 \mathrm{~B}^{*}$ & Stack Monitor Station \\
\hline $292 \mathrm{~B}$ & SWP Change Trailer \\
\hline MO-537 & SWP Change Trailer \\
\hline $\begin{array}{l}\text { MO-029, MO-232, } \\
\text { MO-410, MO-995 }\end{array}$ & Mobile Offices \\
\hline
\end{tabular}


Table 2-1. B Plant Transition Project Buildings/Facilities.

\begin{tabular}{|c|c|}
\hline - Bularing thatity & 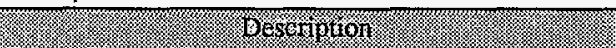 \\
\hline Unplanned Release Sites & 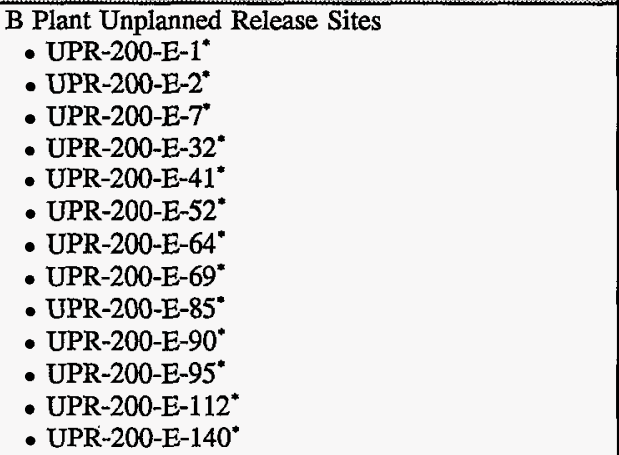 \\
\hline
\end{tabular}

Note:

Denotes materials or units within facility are regulated or potentially regulated. 
WHC-EP-0895, Rev. 0

This page intentionally left blank. 


\subsection{PROJECT OBJECTIVES}

The overall goal of the B Plant Transition Project is to complete B Plant deactivation by September 30, 1998, and turnover B Plant in fiscal year 1999 for cost effective, long term S\&M. The key performance measures that support the accomplishment of this goal are as follows:

- Eliminate or mitigate major hazards

- $\quad$ Reduce S\&M costs by $90 \%$ and prepare S\&M Plan

- Ensure control/operability of systems and equipment required to support postdeactivation S\&M for a 10 year period

- Deactivate all other systems and equipment

- Maintain environmental, safety, and health compliance

- Complete turnover of B Plant and data package for S\&M phase.

At the completion of transition, B Plant will be unoccupied, locked, and hazards will have been removed or mitigated to an acceptable risk level. Systems and utilities within the associated confinement structures will be deactivated unless they are required to support the Surveillance and Maintenance (S\&M) phase of B Plant decommissioning. Periodic surveillance will be performed for industrial safety and security. Required monitoring or operation of active systems (such as canyon ventilation) will be done remotely, with active components located outside the confinement structures to the extent practicable. The only required routine maintenance activity is anticipated to be associated with the canyon ventilation. All deactivation end points will have been met. WESF will be isolated from B Plant for stand alone operation.

Transition of B Plant will result in a vast reduction of the hazards and risks associated with these facilities and will greatly reduce the costs of surveilling and maintaining these facilities until the disposition phase is initiated. Using PUREX as the model for transition, including lessons learned from PUREX and other deactivation projects, further improvement on the transition model can be realized as a result of the B Plant Transition Project. 
WHC-EP-0895, Rev. 0

This page intentionally left blank. 


\subsection{PROJECT ORGANIZATION}

\subsection{PROJECT MANAGEMENT TEAM}

A Project Management Team has been established as the overall top level management and decision making authority for the B Plant Transition Project. The team is made up of a single high level official from each of the three primary agencies/companies responsible to oversee and manage the B Plant Transition Project to ensure success. It includes a representative from the U.S. Department of Energy-Headquarters (DOE-HQ), Office of Nuclear Materials and Facility Stabilization (EM-60), a representative from the U.S. Department of Energy, Richland Operations Office (RL), Transition Projects Division, and a representative from the Westinghouse Hanford Company (WHC), B Plant Transition Project. This team is the primary decision making authority and focal point for stakeholder involvement and communications. Each team member plays a critical role, in that they carry the responsibility of being the single point of contact between their agency/company and the B Plant Transition Project. Formal communications with external organizations such as the Washington State Department of Ecology and the U.S. Environmental Protection Agency are carried out through the team. Informal interfaces between B Plant Transition Project staff and external organizations are carried out at appropriate levels within each agency/company, as approved and directed by the team.

\subsection{WHC PROJECT MANAGEMENT STRUCTURE}

The WHC project management structure being used for the B Plant/WESF Transition Project consists of the "reengineered" management structure shown in Figure 4-1. This organization is headed by the B Plant/WESF Transition Project Director and the B Plant/WESF Complex Director, who serves as a deputy to the Project Director. Reporting to the directors are Support Group and Project Activity Managers (PAMs), as well as Safety and Regulatory Compliance Officers. Together, the directors and their reporting managers and officers make up the Project Management Team for B Plant/WESF.

The primary responsibility for facility operations, continuing surveillance and maintenance activities, and deactivation efforts will reside with the PAMs and the project/facility teams assigned to the PAMs, as shown on Figure 4-1. The majority of work within the B Plant/WESF Transition Project will be organized into project/facility teams, led by team leaders selected by the Project Management Team for B Plant/WESF. These project/facility teams will be resource loaded to accomplish their assigned work. During the transition phase, where surveillance and maintenance operations are reduced from their historical level to a level commensurate with "minimal surveillance and maintenance," resources are distributed accordingly to ensure that safety and environmental compliance requirements are met, while deactivation efforts are initiated and completed. The closer B Plant moves toward 
completion of transition, the more heavily resources will be shifted to work on deactivation activities. Project Activity Managers and Team Leaders are assigned the work and given responsibility for scope, cost, and schedule associated with that work.

Coordination of work between the various teams and groups is orchestrated by the B Plant/WESF Near Term Planning Team, which is headed by the project/facility team leaders. This planning team (team leaders) works closely together assigning and shifting work and resources to complete assigned tasks, enhance productivity, and achieve cost effective implementation of transition activities.

Transition of B Plant within a three year period requires maximum personnel flexibility and innovative organizational approaches, such as reengineering and self-directed teams, to meet the ever demanding/changing need for resources. This organization more closely aligns resources to the facilities/projects they support and utilizes self directed project/facility teams to accomplish work more effectively and efficiently.

The reengineered organization shown below and described in this section is in development and will change a number of times over the life of the project. Changes in organizational structure will not be maintained current in the PMP, but, will be updated as other revisions are made to this document. 
Figure 4-1. B Plant/WESF Transition Project Management Organization.

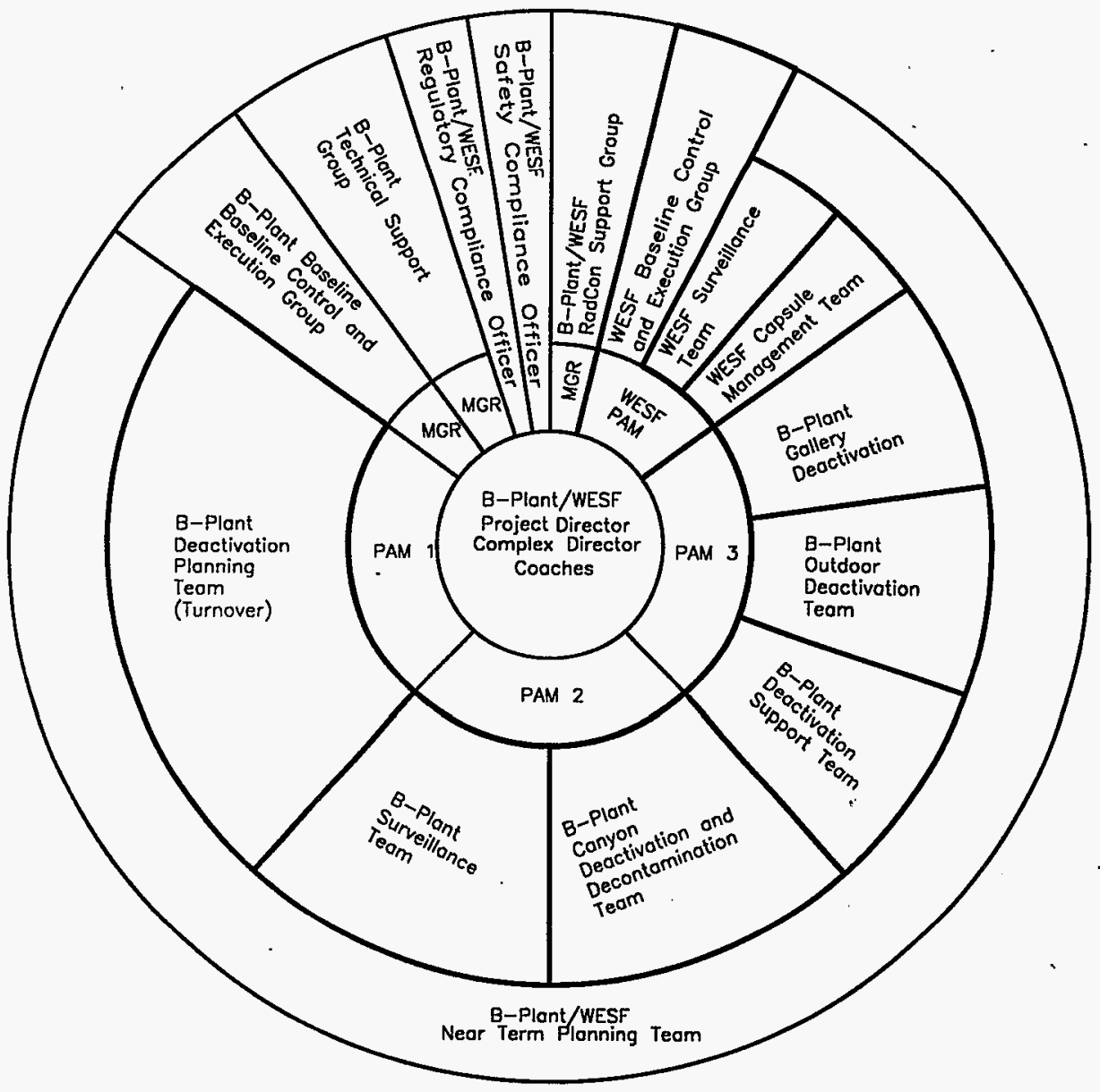

PAM = Project Activity Manoger 
WHC-EP-0895, Rev. 0

This page intentionally left blank. 


\subsection{PROJECT MANAGEMENT AND CONTROL}

The Project Management and Control systems to be used for the B Plant Transition Project are contained in WHC-CM-2-5, "Management Control System."

Transition work scope is organized into a Work Breakdown Structure (WBS), as shown in Figure 5-1, where the work is organized into major projects which are further broken down into more detailed tasks and sub-tasks necessary to accomplish the major projects. Based on the WBS and the estimate of resources needed to accomplish each major project, task, or sub-task, resource loaded working schedules are developed. Progress is formally statused and reported monthly through the Site Management System Report and includes accomplishments, progress toward milestones, financial status, planned activities, and issues. Periodic project reviews will be conducted by the Project Management Team for interested stakeholders. Technical scope, schedule, and cost information is contained in WHC-SP1126, "Transition Projects MultiYear Program Plan" (see Section 11.1).

In the event that it becomes necessary to change the baselines (technical, schedule, and cost), the changes will be managed in accordance with WHC-CM-2-5.

The WBS structure depicted in Figure 5-1 highlights those activities directly related to the B Plant Transition Project. The full details of the WBS structure are contained in the MultiYear Program Plan (MYPP) (Section 11.1). 
Figure 5-1. WBS - B Plant Transition Project.

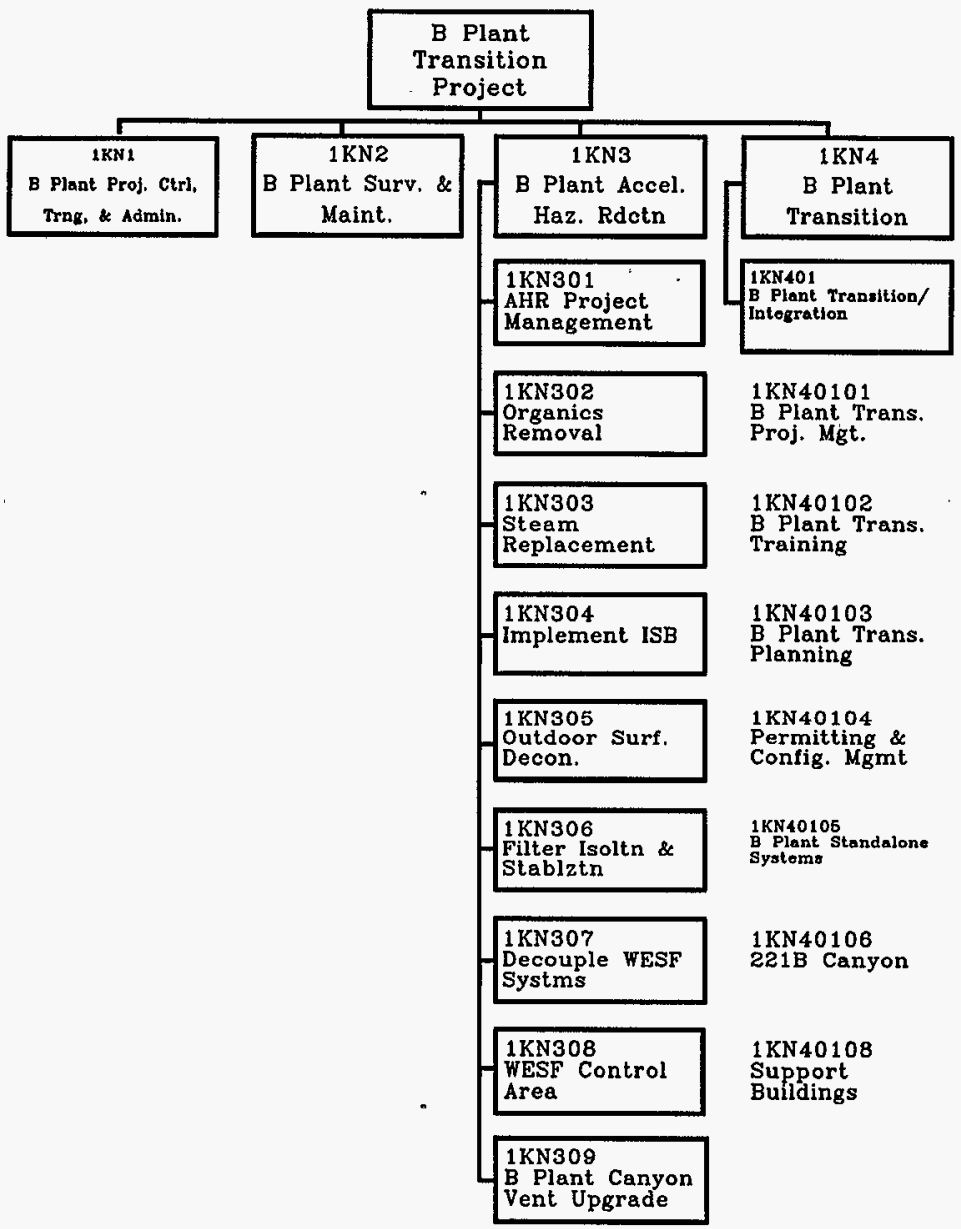




\subsection{PROJECT BASELINE}

The detailed B Plant Transition Project baseline is developed and presented in WHC-SP-1126, "Transition Projects MultiYear Program Plan" (see Section 11.1). This Program Plan (referred to as the MYPP) establishes scope, cost, and schedule for the B Plant Transition Project, in accordance with established end points. The MYPP specifies all milestones and deliverables, establishes both short term and long term schedules, and provides details on the financial, human, and material resources needed to accomplish the transition work according to the established schedules. It forms the project baseline in terms of both cost and schedule and serves as the vehicle for obtaining Department of Energy approval of the planned transition work. The MYPP also identifies the objectives, assumptions, and constraints related to accomplishing the baseline workscope. Revisions to the baseline are accomplished as described in Section 5.0.

The B Plant/WESF cost and schedule baseline has been revised to include the accelerated three year project commitment ("breakthrough") and incorporate the associated Activity Based Cost estimates. The current baseline schedule (summary level) for the three year transition phase is shown in Figure 6-1. 
WHC-EP-0895, Rev. 0

Figure 6-1. B Plant Transition Project - Baseline Schedule. (2 pages)

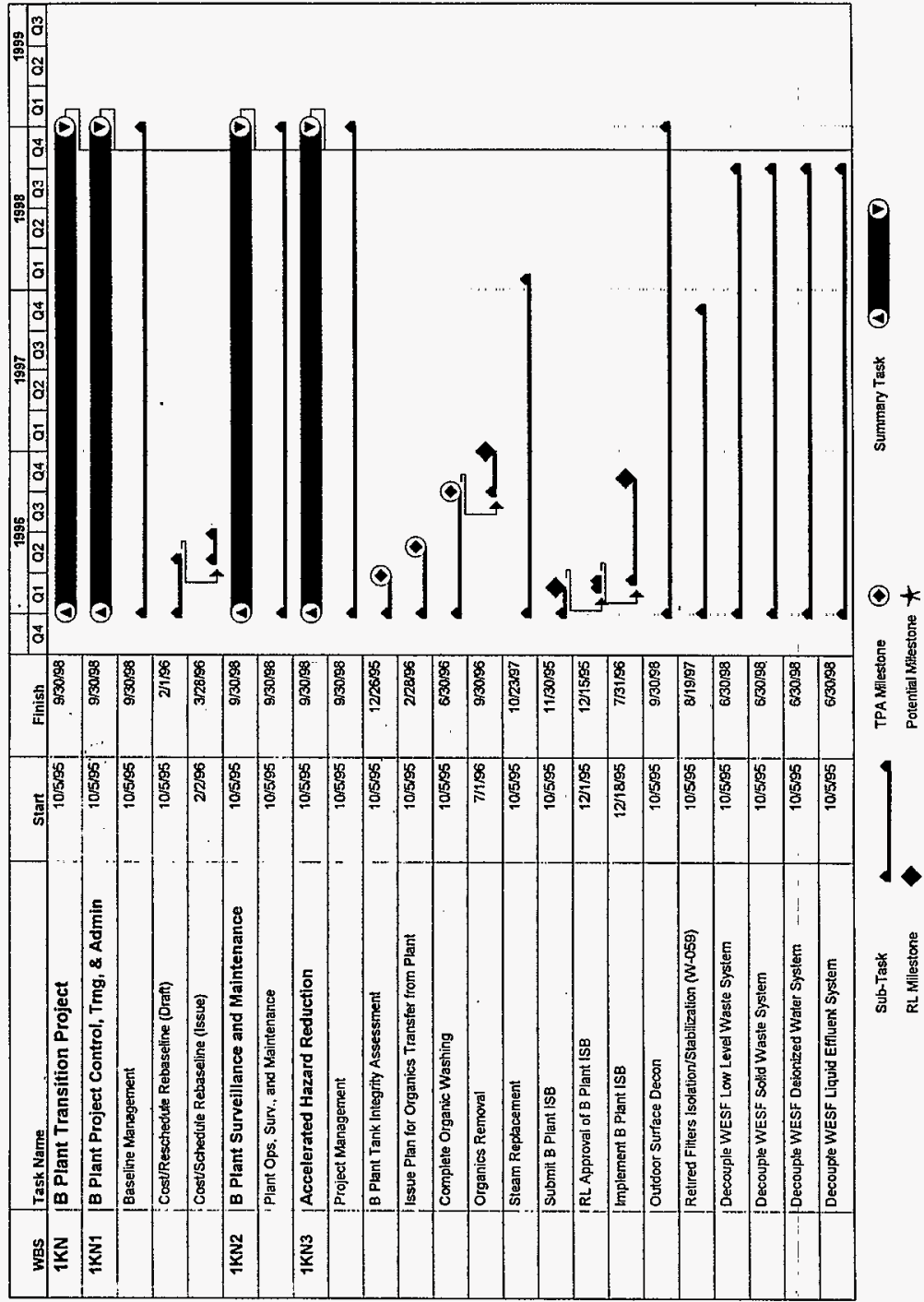


WHC-EP-0895, Rev. 0

Figure 6-1. B Plant Transition Project - Baseline Schedule. (2 pages)
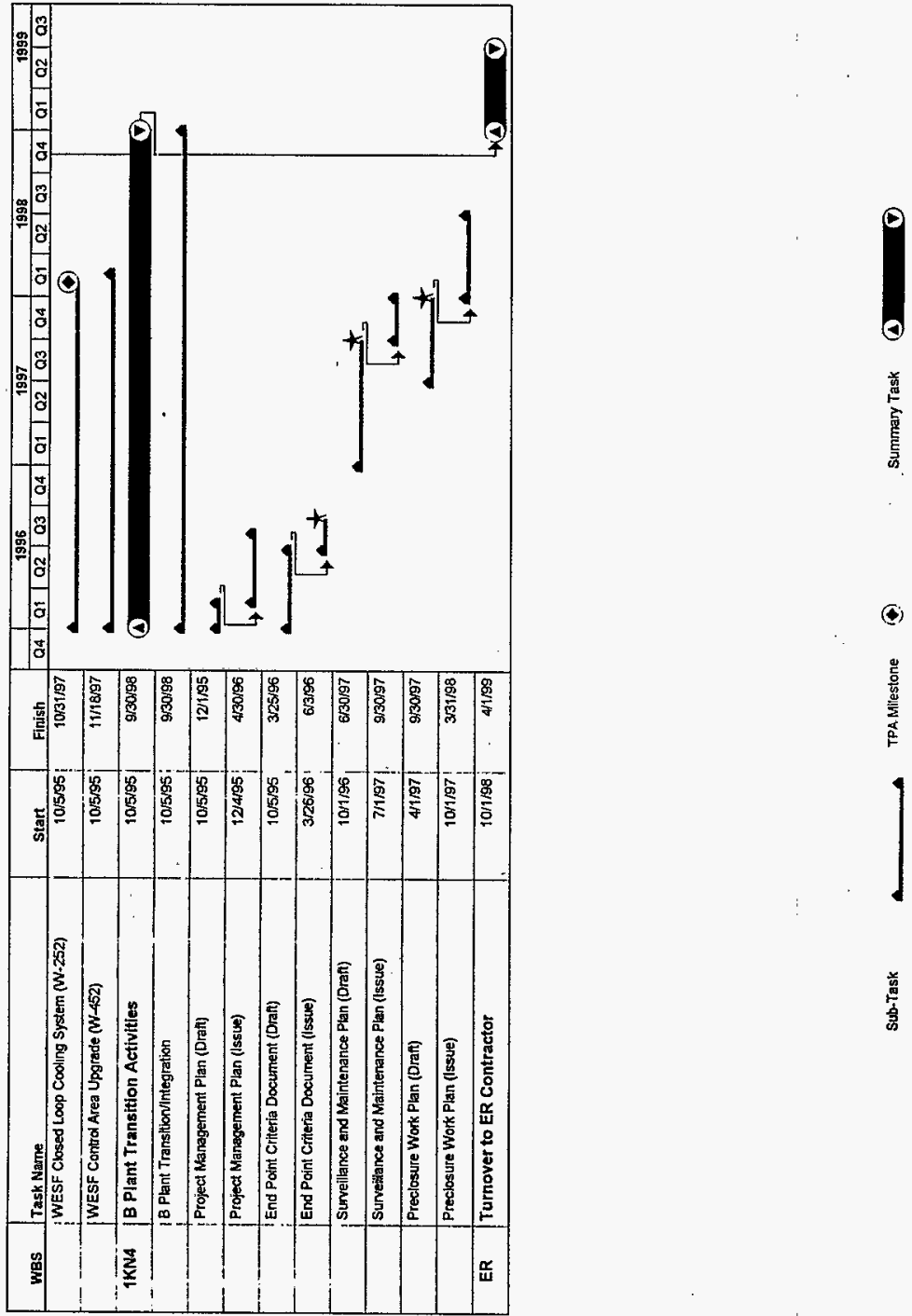

总

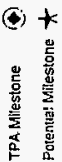

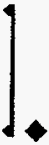

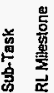


WHC-EP-0895, Rev. 0

This page intentionally left blank. 


\subsection{DEACTIVATION END POINTS}

The Office of Nuclear Material and Facility Stabilization (EM-60) has directed that end points planning is essential and required for accomplishing deactivation. An end point method is a way to translate a broad mission statement into explicit goals and objectives that are readily understood by engineers and crafts who do the work. It identifies when activities are complete, defines the baseline facility condition for long term S\&M, and establishes the method for turnover to EM-40. A successful end point development requires ownership by all affected organizations, including project planners, those who implement the plans, and the ultimate customers (EM-40).

The B Plant strategy for end point development seeks to apply experience from other EM-60 projects, per the guidelines provided, while meeting the requirement of a formal project management approach. The method proposed below maximizes the use of lessons learned from these projects.

The overall facility end points must be decided very early in the deactivation planning because the end points provide the foundation for the activities and schedules associated with the transition project, as reflected in the MYPP.

\subsection{EARLY ASSUMPTIONS FOR B PLANT}

Several deactivation tasks will be required regardless of the details of the final end points. These activities can be planned and initiated early in the transition planning phase of B Plant decommissioning, in parallel with preparation of the final end points. Those early decisions that have been determined to fit this criteria and are proceeding in parallel with end point development, are as follows:

- $\quad$ Organics Removal - Removal of organic liquids from the 221-B canyon is required as soon as possible. This radioactive liquid solvent mixture is a legacy of the solvent extraction strontium recovery process shutdown in 1979. Alternatives for removal of the liquid organic include transfer from B Plant canyon to a suitable container for immediate transport to a disposal site, transfer to a suitable storage tank for interim storage until a disposal option becomes available, transfer to Tank Waste Remediation Systems for storage/disposal, or other on-site disposal through the use of alternate iechnologies.

- Tank/Vessel Management - Removal of radioactive and hazardous liquids from B Plant tanks and vessels, similar to PUREX, is assumed and has been initiated, in parallel with the development of a final management strategy and associated end points. Determination of remaining liquid inventory in 
tanks/vessels and methods for removal are being initiated early in the transition planning phase to reduce future permitting, closure, and S\&M costs.

- Canyon Ventilation System - The need for an operating canyon ventilation system is an early assumption to support the S\&M phase of B Plant decommissioning. Retired, underground, B Plant canyon filters contain a large inventory of radioactive strontium and cesium. The filter design prevents total isolation of loaded filters because the retired filters and the active filter share a common inlet plenum. In addition, it is assumed that an end point will require that the outlet water seals be replaced with an alternative, more permanent, method of isolation. An early assumption has been made to isolate the retired/old filter banks and to construct a new system under Project W-059. This will place the retired filters into a safe, stable shutdown condition for the S\&M phase, pending their ultimate disposition.

- WESF Decoupling - The isolation or "Decoupling" of WESF from B Plant, will be needed to complete the B Plant Transition Project. B Plant currently supports the WESF mission by supplying deionized water, receiving and disposing of low level liquid waste, receiving solid waste, and receiving and monitoring effluent streams. The deionized water needs for the WESF pool cells will be met by a new system or service contract provided exclusively for WESF, allowing deactivation of the large deionized water system located in B Plant. Low level liquid waste generated in WESF will be collected and disposed to Tank Farms or an alternate disposal site, as appropriate. Solid waste generated at WESF will be packaged for direct transport to burial grounds or storage facilities operated by Solid Waste. Liquid effluents generated by WESF will be reduced and rerouted to flow directly to the 200 Area Treated Effluent Disposal Facility (TEDF) through a combination of building a new closed loop cooling system for WESF (Project W-252) and tiein to the chemical sewer stream. This will allow for isolation of B Plant liquid effluents and provide capability to handle WESF liquid effluents independent of B Plant.

- Bulk Chemical Removal - The deactivation of B Plant bulk chemical systems and removal of chemicals began several years ago and was completed in 1995 to reduce chemical exposure hazards to personnel. In addition to the removal of unneeded chemical equipment, the following activities were completed:

1) nine vertical tanks in the $211 \mathrm{~B}$ chemical tank farm were emptied of residual liquids, cleaned, physically removed for reuse on the Hanford Site, and all remaining piping associated with these tanks was removed.

2) approximately 20 tanks in the 271B 3rd floor Aqueous Makeup area were emptied of residual liquids, cleaned, and associated piping was removed. 
3) tanks in the 276B Building were emptied of residual liquids, cleaned, and removed from the building.

4) bulk sodium hydroxide $(\mathrm{NaOH})$ was removed from B Plant in 1995.

- Interim Safety Basis Development - The existing safety basis for B Plant is outdated and in need of complete revision to reflect the change in facility mission. The existing B Plant Safety Analysis Report is based on previous strontium and cesium processing and does not recognize the current transition mission. An Interim Safety Basis (ISB) is currently being prepared to provide an accurate safety basis for the transition phase of B Plant decommissioning. The ISB will initially reflect ongoing and anticipated transition activities and will be updated as needed during the transition phase to reflect changes in plant conditions, as systems are deactivated for entering the S\&M phase.

- $\quad$ Steam Elimination - B Plant currently relies on steam to operate solution transfer jets, steam heaters for process and building heat, and steam driven backup ventilation systems. Elimination of steam has been initiated to reduce the costs of operating and maintaining the steam supply systems.

- $\quad$ Outdoor Surface Decontamination - Routine maintenance and operations at B Plant requires work in radiologically contaminated areas. These contaminated or potentially contaminated areas involve extra cost and hazard exposure to workers over work in totally "clean" areas. To reduce cost and hazard exposure, efforts are ongoing to reduce B Plant radiological contamination areas.

\subsection{END POINTS METHOD}

The "end points" method for B Plant will duplicate the successful process developed and tested at PUREX, following the EM-60 guidance published in "Facility Deactivation End Points Method and Examples." These methods of defining end points for facility stabilization and deactivation have proven to be extremely effective in planning work and interacting with the regulators and environmental restoration contractors responsible for post deactivation S\&M.

The end point method is a logical process of determining final conditions for each of B Plant's systems and spaces. The final conditions are based on stated objectives, likely task types, and expected future uses for the systems and spaces.

Several guiding principles form the foundation of the end point process:

- The decision to create an end point should be driven by, and clearly linked to, top-tier program objectives, not by feasibility or capability, 
- The end point condition of B Plant should employ a fundamental safety approach. This involves three layers of protection: elimination of hazards, effective facility containment, and facility monitoring and control,

- End point decisions are integrally linked to decisions (and constraints) on resources and methods. Cost effectiveness is important,

- A successful end point development requires ownership by all affected organizations including project planners, those who implement the plans, and the ultimate customers (EM-40),

- Work teams in the field need clear, quantitative end points. They can't work effectively with vague or functional objectives,

- It is not known when or what the ultimate facility disposition will be. Therefore, end point decisions should not be driven by dispositioning presumptions, and

- End point development is an iterative process. Some end point decisions may have to be revisited as the deactivation proceeds.

Every end point is driven by an objective; therefore the first step is to define the top level objectives (in concurrence with the environmental restoration contractor), which will then form the objectives for the end points. For B Plant these objectives are:

- Protecting the public and the environment,

- Facilitating long term S\&M,

- Facilitating the ultimate Disposition work,

- Complying with regulations and requirements, and

- Following through on commitments to stakeholders.

Task areas are the series of tasks which take the facility from its existing state, with hazards and conditions resulting from its lifetime of operation, to its deactivated state. For B Plant deactivation, the following Task Areas are to be used throughout the end point development process:

- Hazards - Nuclear and non-nuclear. Activities include removing, isolating, draining and minimizing activities.

- Radiation Fields - Activities include removing, shielding, documenting and ensuring the proper radiological posting of remaining radiation areas. 
- Contamination - Activities include decontaminating, isolating, fixing, documenting and ensuring the proper radiological posting of contamination areas.

- Waste - Compliance with regulations and requirements generates activities that include removing, flushing, excessing, permitting and disposing of waste.

- Isolate and Contain - Activities include blanking, plugging, covering, removing, screening, and sealing of doors, windows, pipe penetrations, holes, drains, etc.

- Monitor and Control - Provides the necessary activities required to support and minimize the cost, risk and hazards involved with the future S\&M of the facility. Examples are instrumentation, installation of windows in ancillary buildings, and providing surveillance lighting.

- Refurbish or Install - Activities include structural repairs and roof sealing and the modification of the facility ventilation system.

- Document and Label - Activities cover the documentation and labeling required for the specific space or system.

Finally, B Plant is comprised of spaces and systems for which end points need to be established. The spaces and systems are classified, in terms of their intended deactivated condition, into the following six (6) cases:

- Internal spaces for which routine access will be required for post-deactivation S\&M,

- Internal spaces for which access is not expected for post deactivation S\&M,

- External spaces including building exterior envelopes,

- Systems/equipment which must be operable for post deactivation S\&M,

- Systems/equipment to be mothballed (i.e. judged to be useful for the disposition phase of decommissioning), and

- Systems/equipment to be abandoned in place.

The end point methods described above are not intended to be prescriptive in nature, but, are to be adapted to suit the specific needs of the facility under transition. The detailed end points for B Plant are contained in the End Point Criteria Document (Section 11.2). 
WHC-EP-0895, Rev. 0

This page intentionally left blank. 


\subsection{QUALITY ASSURANCE}

\subsection{QUALITY POLICIES}

Quality Assurance for the transition phase of B Plant decommissioning will be implemented as specified in the "Quality Policies" (QP) contained in WHC-CM-5-6, B Plant/WESF Transition Project Administration, Section 10.0. These 10 quality policies constitute the Quality Management System of B Plant/WESF Transition Project and are binding on all B Plant/WESF organizations and all activities conducted by WHC, its contractors, and sub-contractors within the B Plant/WESF complex.

The quality policies contained in WHC-CM-5-6 are prepared in accordance with the Standards/Requirements Identification Documents (S/RIDs) for B Plant and WESF facilities. Implementation of these quality requirements meets the requirements of 10 CFR 830.120 , "Quality Assurance Requirements" (QA Rule), and WHC-CM-4-2, Quality Assurance Manual. The following is a list of the B Plant/WESF quality policies:

$\begin{array}{ll}\text { QP 1.0 } & \text { Management Responsibilities and Quality System } \\ \text { QP 2.0 } & \text { Personnel Training and Qualification } \\ \text { QP 3.0 } & \text { Quality Improvement System } \\ \text { QP 4.0 } & \text { Document and Record Control } \\ \text { QP 5.0 } & \text { Work Process, Item, and Equipment Control } \\ \text { QP 6.0 } & \text { Design Process Control } \\ \text { QP 7.0 } & \text { Procurement } \\ \text { QP 8.0 } & \text { Inspection and Acceptance Testing } \\ \text { QP 9.0 } & \text { Management Assessments } \\ \text { QP 10.0 } & \text { Independent Assessments. }\end{array}$

Implementation of these quality policies will be accomplished using a graded approach. The quality controls and systems applicable to transition activities will depend on the importance of those activities to the success of the B Plant Transition Project. 


\subsection{CONFIGURATION MANAGEMENT}

Configuration management for B Plant structures, systems, and components (SSCs) will be performed in accordance with the category of anticipated disposition for each SSC. The categories and the guidance for configuration management are as follows:

1. SSCs that must remain in limited operation - drawings, vendor information, and appropriate design bases (i.e. requirements depicting documentation) will be maintained during the remaining limited operations of SSCs.

2. SSCs that will be removed and re-used - all requirements depicting documentation will be transferred with the SSC to the receiving organization.

3. Surplus SSCs that will be deactivated, remain in place (abandoned), or moved, stored, and maintained in an environmentally sound condition until final disposition - all requirements depicting documentation will be stored until the disposition of the SSC has been determined.

4. Surplus SSCs that will be removed and disposed of - as an SSC is removed, the documents that were required to support the design, operation, or use of the SSC will be voided.

5. Surplus and non-operating SSCs that will be turned over for ultimate disposition - all existing requirements depicting documentation will be submitted to the disposition contractor as part of the turnover package.

Systems that are shut down or otherwise deactivated will be labeled or tagged as such (at key control points) with a label or tag that lists the work package that authorized the deactivation and the date completed.

\subsection{DOCUMENTS AND RECORDS}

The process of transitioning B Plant to a safe, stable shutdown condition will need to be properly managed to ensure documents and records are available to support the S\&M phase, as well as the disposition phase of B Plant decommissioning. These documents and records will be categorized, marked, maintained, stored, and archived in accordance with the quality policies described above with emphasis on documents and records that support contractual requirements or aid in the execution and/or planning of the transition, S\&M, or disposition phases of B Plant decommissioning. Documents and records generated during B Plant deactivation activities and assembled as a means of documenting completion of end points will form the bulk of the files turned over to the environmental restoration contractor. Additional informational documents and records will also be included in the turnover files, as needed and/or requested as part of transition. 


\subsection{ENVIRONMENT, SAFETY AND HEALTH}

The following is a summary of the environment, safety, and health strategies to be employed during the B Plant transition phase to ensure the safety of the environment, the public, and the facility worker.

\subsection{ENVIRONMENTAL REGULATORY STRATEGY}

The strategy for environmental compliance throughout B Plant transition is to apply the process described in the Tri-Party Agreement, Sixth Amendment, Section 8.0, "Facility Decommissioning Process," and to apply the lessons learned from PUREX transition and other deactivation projects for environmental/regulatory process improvement. The overall goal of this strategy is to comply with all applicable environmental laws and regulations during B Plant transition.

The following discussion provides the status of major compliance areas, and discusses the strategy associated with each:

- $\quad$ RCRA Status/Strategy - B Plant currently manages six dangerous waste units under the treatment, storage, and disposal requirements of Washington State Dangerous Waste regulations, WAC 173-303. These units are described in the "Hanford Facility Dangerous Waste Part A Permit Application, Form 3, Revision 2, For the B Plant Complex (WA7890008967) (TSD: S-2-3) (Part A)." The TSD units are operated in compliance with applicable interim status requirements of 40 CFR 265, and "Tri-Party Agreement" milestones.

Endpoint criteria for the TSD units will be determined using PUREX as a model and shall provide the requirements to minimize hazards in the TSD units and the basis for detailed actions described in the Preclosure Work Plan. These actions will facilitate the long term S\&M and disposition phases of B Plant decommissioning.

- Clean Air Act Status/Strategy - all new activities, construction, and/or modifications at B Plant that have the potential for increasing radioactive air emissions are required to be evaluated through the Notice of Construction Process. Any activity requiring a notice of construction will also require an update of the Air Operating. Permit that takes effect in November of 1997.

The B Plant Stack (291-B-1) is considered a major stack under NESHAPs regulations and is the only major stack at B Plant. Under these regulations, continuous monitoring is required. However, in conjunction with transition activities, a NESHAPs assessment will be performed to evaluate reducing this stack to a minor stack after transition is complete. Status as a minor stack 
would only require periodic confirmatory measurements. Stacks $296-\mathrm{B}-5$ and 296-B-13 are associated with buildings 221-BB and 221-BF. These stacks are minor stacks under NESHAPs regulations and plans include isolating and removing them from the Department of Health registered stacks list.

- Clean Water Act/Safe Drinking Water Act Status/Strategy - B Plant currently manages two liquid effluent streams: the B Plant Cooling Water (CBC) stream and the B Plant Chemical Effluent (BCE) stream. Both B Plant and WESF contribute to these streams.

Contributors to the $\mathrm{CBC}$ include high-risk cooling water from B Plant and low-risk cooling water from the WESF pool cells. During transition, elimination of the high-risk cooling water from B Plant and the completion of Project W-252, which provides closed loop cooling for WESF pool cells, will eliminate the CBC effluent discharge to B-Pond (TPA milestone M-17-00B).

Contributors to the BCE include chemical sewer effluent from B Plant, floor drains in B Plant, WESF, and the maintenance shops, and cooling water effluent from the various air compressors in B Plant and WESF. Although transition activities will eliminate the B Plant sources and reduce the overall $B C E$ flow, the stream will not be eliminated entirely. Effluent from the WESF closed loop cooling system will be combined with the reduced flow BCE and rerouted to the 200 Area Treated Effluent Disposal Facility, which is operated under a 216 State of Washington Wastewater Discharge Permit.

- National Environmental Policy Act (NEPA)/State Environmental Policy Act (SEPA) Status/Strategy - waste management operations at B Plant are provided NEPA coverage under the "Final Environmental Impact Statement-Waste Management Operations, Hanford Reservation (ERDA-1538), " written in December 1975. This document addresses the environmental impacts of such operations as liquid waste transfers, solid waste generation and disposal, management of gaseous effluents, management of liquid effluents, as well as other functions that are no longer performed at B Plant (e.g. NCAW pretreatment, $\mathrm{Sr}$ and $\mathrm{Cs}$ recovery, etc.).

Except for decoupling of B Plant and WESF, transition activities currently planned and/or underway (early assumptions being initiated in parallel with end point development) are being addressed in a Categorical Exclusion/Information Bulletin. NEPA documentation for the decoupling of WESF is under development.

Deactivation efforts outside the scope of activities covered under the above mentioned NEPA documentation, could potentially require the preparation of additional NEPA documentation. As the transition planning is developed, the 
work scope for transition activities will be evaluated to determine the proper level of required NEPA documentation. A similar approach was used successfully for the PUREX deactivation project.

State and local government agencies are required to comply with SEPA before any permit is issued. Compliance is initiated by submission of a completed SEPA environmental checklist. A SEPA environmental checklist will accompany the B Plant Preclosure Work Plan.

- National Historic Preservation Act (NHPA) Status/Strategy - NHPA provisions found in 36 CFR 63, "Determination of Eligibility for Inclusion in National Register," require Federal agencies to survey all lands under their control and evaluate all identified historic properties for their eligibility for listing in the National Register of Historic Places. The Washington State Historic Preservation Office requires that a Historic Property Inventory Form be completed and filed for all Hanford properties identified during these surveys.

Two B Plant/WESF structures have the potential to be impacted by the provisions of the NHPA, 221-B and 225-B. The two facilities are unique as they were the only facilities in the DOE Complex to be used for cesium and strontium recovery operations. No major modifications or alterations to these facility structures (including modification/removal of equipment and facility hardware) may take place until the historic documentation is in place.

RL and the State Historic Preservation Officer (SHPO) are currently negotiating a sitewide mitigation plan commensurate with the requirements of the NHPA. Until such time this agreement is reached, activities planned under the B Plant transition project will be evaluated as necessary to evaluate adverse effects to the historic significance of the facility.

- Tri-Party Agreement Milestones - on January 3, 1996 (within three months of receiving a formal notice of facility shutdown from DOE-HQ), RL initiated negotiations with stakeholders in the development of B Plant Transition Project milestones. Using the PUREX model and lessons learned from previous deactivation projects, the expected outcome of negotiations will be a proposed set of TPA milestones for the transition phase of B Plant decommissioning, consistent with the PUREX examples. Major milestones, Interim milestones, and target actions will form the basis for B Plant transition work and shall coincide with early assumptions and end points developed for B Plant transition. 


\subsection{HEALTH AND SAFETY STRATEGY}

An integrated process for nuclear safety and worker safety and health will be employed at B Plant to ensure the safety of the environment, the public and the facility workers against nuclear and non-nuclear hazards encountered during transition. This process will consist of two major parts:

- Evaluation of activities with respect to bounding conditions described in the safety basis (unreviewed safety question process), and

- Identification and management of all types of hazards to the environment, public, and facility workers.

This integrated safety process will be implemented during the work planning stage to identify and overcome problems before work processes are developed for specific deactivation activities. The process will facilitate work by identifying key hazards up front and incorporating risk management into the job planning process. The goal is to allow work to be performed in accordance with the approved safety basis and in a manner protective of the environment, public and facility worker.

\subsubsection{Safety Basis Evaluation of Activities}

Deactivation activities will be evaluated against the approved safety basis to identify any potential "unreviewed safety questions" (USQs). If the activity is covered by the analysis in the safety basis, no additional safety basis documentation or evaluation is required. If the activity is not covered, then either the work plans must be modified to stay within the bounds of the existing safety basis or the safety basis must be modified through additional safety analysis. Once approved by RL, the new analysis would become part of the approved safety basis. The existing safety basis for B Plant is contained within the following documents:

- WHC-SD-WM-SAR-013, "B Plant Safety Analysis Report"

- WHC-SD-WM-SAR-008, "212B Cask Station Facility Hazards Identification and Evaluation"

- WHC-SD-WM-TI-554, "B Plant Exhaust Filter Outlet Seal Analysis."

The existing safety basis for B Plant is being updated for transition. Deactivation activities have been evaluated to identify credible radiological and non-radiological accidents. Those accidents have been analyzed to identify restrictions and operating controls necessary to provide adequate safety for transition activities. This updated safety analysis, consisting of the following documents, has been submitted to RL for approval:

- WHC-SD-WM-ISB-008, "B Plant Interim Safety Basis" 


\section{- WHC-SD-WM-SARR-030, "B Plant Interim Safety Basis Accident Analysis"}

- WHC-SD-WM-TM-004, "B Plant Facility Description"

After RL approval and B Plant implementation of the requirements they contain, these three documents will then comprise the B Plant safety basis for transition. The USQ process will continue to be used to ensure that deactivation activities are conducted within the bounds of the safety basis. As new deactivation activities are undertaken, the work plans will either be modified to satisfy the requirements of the updated safety basis or new analyses will be performed and incorporated into the safety basis to ensure adequate safety of transition activities.

\subsubsection{Assessment of Hazards}

Upon completion of the above safety basis evaluation, proposed deactivation activities will be evaluated for hazards and appropriate hazards mitigation measures will be incorporated into work plans.

Activity specific hazards screening and evaluation is performed for each work activity (or major work task) by an experienced facility subject matter expert. The screening will identify the characteristics of the task (complexity, hazard, process, etc.), the experience base at the plant for this or similar tasks, the real and/or perceived risks involved with the task, and the questions related to potential problems/accidents that could occur during the task. The screening will be documented on the Preliminary Hazards/Screening Assessment (PHSA) form and will provide the basis for the identification of the appropriate level of additional analysis/evaluation. Using the information on the PHSA form, the cognizant engineer and facility personnel will recommend one of three levels of analysis be performed on the work activity:

Level 1 The minimal analysis (Level 1 - low risk/consequence) will involve completion of the work activity following existing requirements and procedures. This includes completion of a hazards checklist and review/approval of the proposed work activity, as designated by the cognizant engineer.

Level 2 The intermediate level of analysis (Level 2 - medium risk/consequence) requires the performance of a Job Safety Analysis (JSA), in addition to following existing requirements and procedures. The JSA is performed by a small team (includes cognizant engineer, appropriate safety professionals, training representative, facility worker, and team lead) who review the proposed work activity section by section and identify any specific hazards associated with the completion of each procedure section. The team also identifies any programs or systems that are particularly critical to the safe 
execution of the proposed work activity and makes recommendations as to the appropriate controls and/or reviews necessary to prevent, control, or mitigate the identified hazards.

Level 3 The highest level of analysis (Level 3 - high risk/consequence) requires the performance of a more formal and detailed hazards analysis technique, such as a Hazards and Operability Study or Preliminary Hazards Analysis, in addition to following existing requirements and procedures. This analysis will be performed by a team similar to the JSA team with the addition of a qualified, experienced, hazards analyst. The team will include in their evaluation a review of the S/RIDs functional areas, on an item by item basis, to determine any critical programs or systems for the safe execution of the proposed work activity. The team will then make recommendations regarding the necessary controls to prevent, control, or mitigate the identified hazards.

\subsubsection{Worker Safety}

In addition to the hazards assessment program described above, a Comprehensive Baseline Hazards Assessment of the B Plant facility has been performed by WHC safety professionals to examine all areas of the facility and determine the hazards in those areas.

This information will be used and routinely updated to develop hazards recognition training that B Plant employees will receive. The training will focus on hazard identification and how to safely plan and perform work activities within the facility.

The addition of a facility hazards baseline assessment and hazards recognition training will provide additional assurances that worker safety issues are identified as early as possible in the work development process. This will result in early identification of necessary controls to prevent or mitigate worker hazards and aid in the timely completion of the transition effort by reducing the number of injuries or work related safety issues. 


\subsection{COMMUNICATIONS AND PUBLIC INVOLVEMENT}

The transition of B Plant is a critical element in Hanford's mission of environmental management. The B Plant Transition Project Management Team have made a commitment to open communications throughout transition because effective communications and public involvement are critical success factors for the project. Communications must be living and dynamic, responding to accomplishments and emerging issues or activities. $\mathbf{A}$ communications plan will be developed to define specific actions for disseminating information regarding project objectives, strategies, problems/issues, and status, and for developing strategies for soliciting input/involvement throughout the deactivation project. These actions will be targeted at employees, customers, stakeholders, public, and tribal groups.

\subsection{COMMUNICATION OBJECTIVES}

The key communications objectives of the B Plant transition project are:

- Initiate dialogue to achieve understanding of the project, obtain input from, involve and gain the acceptance of all interested parties (employees, customers, regulators, stakeholders, tribes, media, and public) in decisions concerning B Plant transition.

- Publicize successful activities and share project problems/concerns with all interested parties.

\subsection{COMMUNICATION AUDIENCES}

The following parties will need consistent, integrated communications:

- Employees (including management and bargaining unit)

- Customers (including WHC management, RL management, and DOE-HQ)

- Regulatory agencies

- Stakeholders (including Hanford Advisory Board and special interest groups)

- $\quad$ Affected Tribes

- $\quad$ Media

- Public. 
The B Plant Transition Project Management Team and a Communications Project Team will work together to develop and implement all communications strategies.

\subsection{STRATEGY FOR INVOLVEMENT OF INTERESTED PARTIES}

Early and consistent involvement of all interested parties helps decision-makers select solutions that can stand the test of time. Decisions, upcoming decisions, or former decisions being challenged will be a key focus of involvement. Typically, interested groups and individuals want to be involved in each step of the decision-making process, and they want to be involved early.

The B Plant transition project will apply the following strategies to involve customers, regulators, stakeholders, tribes, and public:

- Establish a common understanding of B Plant transition, the need for deactivation, and the challenges involved.

The emphasis in this step is providing the background information needed to understand the problems to be solved or decisions to be made to complete transition. At the same time, efforts will be taken to identify the audiences who want to be involved in the project. This step is critical to ensure that the affected audiences buy-in to the need for deactivation.

- Identify issues or decisions with B Plant transition that are of special interest.

All decisions are not equal. Involvement must revolve around specific activities that affect various groups.

- Establish an issue resolution process for issues or decisions of interest.

Actions or decisions that have a high level of interest or where there are potential tradeoffs between values will require additional interactions to resolve.

- Conduct issue resolution processes, as necessary, to select the best decisions and keep audiences informed of progress in implementing these decisions.

\subsection{EMPLOYEE STRATEGY}

An important communications objective is to raise the awareness level of employees and gain their buy-in to the need for deactivation. Supportive employees who are motivated to make the deactivation project succeed are the most important factor in accomplishing the deactivation project on schedule and within budget constraints. As ambassadors of B Plant 
and the Hanford Site, well informed and supportive employees can convey our cleanup progress, safety performance and transition activities to other interested parties. Because employees are primary communicators, their messages carry special significance to those receiving the messages. Employee communications will help establish an open, two-way communication system between the transition project and the interested parties. Feedback will show employees that their opinions count, that they have a say in how things work, and that they are valued members of the team.

\subsection{MEDIA STRATEGY}

The media strategy for the B Plant Transition Project is to initiate news activities and respond to media inquiries directed to, or received from, local, Northwest and selected national broadcast and print media, with emphasis on the Washington, D.C. trade press to:

- Emphasize the importance of accelerating deactivation of Hanford's former production and processing plants to reduce risk and reduce the mortgage on facilities that are no longer needed.

- Correct inaccurate information, defuse potentially negative issues and secure more balanced media coverage.

- Broaden public understanding and support for the B Plant transition activities specifically and for Hanford cleanup work generally.

Currently, any news about Hanford's challenges or progress must overcome a history of negatives and uncertainties about Hanford, DOE, and site contractors. Achieving more accurate, balanced media coverage can help build clearer understanding, support, and sustained funding for crucial Hanford cleanup work, such as the B Plant transition. Through media reporting, we can reach all interestẹd audiences.

Media outreach will carefully coordinate the timing of messages so that customers, employees, stakeholders and anyone else who is impacted or involved in the work get the news ahead of the general public.

\subsection{COMMUNICATIONS METHODS, CHANNELS, FORMATS, AND DISTRIBUTION}

Our approach to communications will be broad and comprehensive, creative and innovative, and results oriented. Among approaches we will evaluate and use as appropriate are:

- Distribution of informational materials through well established (and underused) existing channels such as public, school, community college, and 
university libraries, Educational Service Districts, and public agency information repositories.

- Televised public meetings and workshops, using video teleconferencing technology where appropriate.

- Use of CD ROM technology.

- Presentations (in person, or by video teleconferencing) to interested audiences.

- Integrated informational materials (print, presentations, video, etc) which present the whole picture, rather than incremental pieces, of the deactivation project. 


\section{1:0 SUPPLEMENT}

The sections included in the PMP as supplements will be available and controlled as separate documents to describe the key strategies and plans for accomplishing the transition of B Plant. A brief description of the scope of each and how it will be controlled is provided below.

\subsection{MULTIYEAR PROGRAM PLAN}

This section contains the most recent revision of document WHC-SP-1126, Transition Projects MultiYear Program Plan. This document is prepared, updated, and maintained in accordance with WHC-CM-2-5, Management Control System.

This program plan establishes scope, cost, and schedule for the B Plant Transition Project, integrating the deactivation activities defined by the end points document. The MYPP specifies all milestones and deliverables, establishes both short term and long term schedules, and provides details on the financial, human, and material resources needed to accomplish the transition work according to the established schedules. It forms the project baseline in terms of both cost and schedule and serves as the vehicle for obtaining Department of Energy approval of the planned transition work. The MYPP also identifies the objectives, assumptions, and constraints related to acçomplishing the baseline workscope.

\subsection{B PLANT DEACTIVATION END POINTS}

This section contains the most recent revision of the WHC-SD-WM-TPP-054, B Plant Deactivation End Points. This document is prepared, updated, and maintained as a supporting document in accordance with WHC-CM-3-6, Uniform Publications System.

The end points document contains facility specific transition end point criteria and established end points (acceptable final conditions of systems and spaces following transition). The end points define the deactivation work that has to be performed during transition, which is integrated into and presented in the MYPP.

\subsection{SURVEILLANCE AND MAINTENANCE PLAN}

This section contains the most recent revision of the B Plant Surveillance and Maintenance Plan (to be developed). This document is prepared, updated, and maintained in accordance with WHC-CM-3-6, Uniform Publications System, until S\&M, at which time it will be converted to an Environmental Restoration contractor document. 
The S\&M plan outlines facility specific activities performed to address essential systems monitoring, maintenance and operations requirements necessary for the transitioned B Plant. The S\&M plan must ensure efficient, cost effective maintenance of B Plant in a safe condition that presents no significant threat of release of hazardous substances into the environment and no significant risk to human health and the environment until disposition of B Plant is completed.

The S\&M Plan is developed in close concert with the Environmental Restoration contractor.

\subsection{PRECLOSURE WORK PLAN}

This section contains the most recent revision of the Preclosure Work Plan (to be developed). This document is prepared, updated, and maintained in accordance with WHC-CM-3-6, Uniform Publications System.

Prior to completion and submittal of a closure plan, a preclosure work plan will be submitted to Ecology and EPA during the transition phase. The preclosure plan is prepared in accordance with Tri-Party Agreement, Section 8.8, "Preclosure Work Plan and RCRA Closure Plan." This preclosure work plan will contain, but is not limited to elements summarized below:

- Facility Description

- Process Information

- Waste Characteristics

- Groundwater Monitoring

- Closure Strategy and Performance Standards

- Closure Activities

- Postclosure Plan.

The preclosure work plan is based in part on the B Plant transition end point criteria document and on the S\&M plan. The transition end point criteria document and the S\&M plan are considered part of the preclosure work plan as they pertain to information related to TSD units.

The preclosure work plan is prepared in cases where completion of RCRA closure activities during the transition or S\&M phases is impracticable. The preclosure work plan details actions to be completed during the transition phase in order to facilitate full RCRA closure in the future. These efforts may include removal of dangerous wastes and hazardous substances and/or removal or decontamination of equipment or structures contaminated with dangerous wastes or hazardous substances.

The preclosure work plan is developed in close concert with the Environmental Restoration contractor. 
WHC-EP-0895, Rev. 0

\section{DISTRIBUTION}

Number of Copies

OFFSITE

2

Department of Energy/Headquarters

R. J. Silva

EM-65

D. MacKenzie

EM-40

Department of Energy/

8

Richland Operations Office

K. A. Benguiat ·

R3-78

B. L. Charboneau

R3-78

D. T. Evans

R3-79

R. X. Gonzalez

R3-79

J. E. Mecca

R3-79

L. L. Piper

R3-78

B. A. Ward

H0-12

A. H. Wirkkala

R3-78

Bechtel Hanford, Inc.

M. R. Morton

X5-53

MACTEC

R. A. Kropp

S6-81

ONSITE

Westinghouse Hanford Company

R. J. Bliss

B3-04

S. D. Godfrey (13)

S6-81

R. E. Heineman, Jr.

S6-60

W. A. Holstein

S4-66

T. L. Main

S6-65

J. C. Midgett

S6-65 


\section{DISTRIBUTION}

Number of Copies

ONSITE

Westinghouse Hanford Company (Continued)

J. I. Pennock

S4-70

D. K. Smith

S6-60

D. W. Wilson

S4-66

Central Files

A3-88

DPT

A3-94 